TP Periodica Polytechnica Chemical Engineering

\author{
62(2), pp. 167-174, 2018 \\ https://doi.org/10.3311/PPch.10667 \\ Creative Commons Attribution (i)
}

RESEARCH ARTICLE

\section{Tetrahymena pyriformis Phagocytic Activity Test for Rapid Toxicity Assessment of Aquatic Micropollutants}

\author{
Ildikó Fekete-Kertész ${ }^{1 *}$, Orsolya Ullmann ${ }^{1}$, Panni Csizmár ${ }^{1}$, \\ Mónika Molnár ${ }^{1}$
}

Received 24 February 2017; accepted after revision 15 August 2017

\begin{abstract}
The increasing worldwide contamination of freshwater ecosystems with micropollutants such as pharmaceuticals, personal care products, hormones, industrial chemicals and pesticides is a key environmental problem facing humanity nowadays. In order to assess the adverse effect of six organic micropollutants (atrazine, bisphenol A, dibutyl phthalate, 17 $\beta$-estradiol, 3,4-dichlorophenol and Na-diclofenac) a short term phagocytic activity test was applied with Tetrahymena pyriformis representing an important trophic level of aquatic ecosystems. Significant concentration-dependent response in phagocytic activity was experienced to $17 \beta$-estradiol and other endocrine disrupting compounds such as 3,4-dichlorophenol, atrazine and dibutyl phthalate with lowest observed effect concentration of 0.01; 0.005; 0.05; $0.05 \mu \mathrm{g} / \mathrm{L}$, respectively. Although bisphenol $A$ and Na-diclofenac did not result in a concentration-dependent response, significant changes in phagocytic activity were observed.

Our results suggest that the phagocytic activity assay relying on a basic cell response can be a valuable method for the early and sensitive indication of adverse effects of micropollutants.
\end{abstract}

\section{Keywords}

ecotoxicity, micropollutants, phagocytic activity, Tetrahymena pyriformis, xenoestrogens

\footnotetext{
${ }^{1}$ Department of Applied Biotechnology and Food Science, Faculty of Chemical Technology and Biotechnology, Budapest University of Technology and Economics, H-1111 Budapest, Szent Gellért sqr. 4., Hungary

*Corresponding author, e-mail: fekete.kertesz.ildi@gmail.com
}

\section{Introduction}

In recent years aquatic micropollutants have raised great concern due to their adverse effects on aquatic organisms even at low concentrations [1-5]. Some of these contaminants exert secondary adverse effects such as endocrine disruption, genotoxicity, neurological and immunological dysfunctions, reprotoxicity and teratogenicity. Compounds with endocrine disrupting features can mimic endogenous estrogens by entering the cell, binding to the receptor and activating transcription. These xenoestrogens may also antagonize normal androgen action [6].

Because of the insufficient limit of detection of conventional ecotoxicology assays, many researchers address the development of innovative tools and sensitive biomarkers for the evaluation of the secondary adverse effects of micropollutants at environmentally relevant concentrations (ng/L- $\mu \mathrm{g} / \mathrm{L})$ [7-10].

There is a wide range of sublethal effects, which can reflect the ecological fitness of individual organisms or a population. Fundamental physiological events in protists, such as phagocytosis can give useful information about the condition of a cell which can be changed by hormonal effects as well $[11,12]$. In protists ciliary movement is not only responsible for locomotion, but feeding as well [12] and it also covers wide potencies for immunological responses [8]. Not only immune related substances, but hormones and hormone analogues can modulate the phagocytic activity [11]. The number of food vacuoles can be affected by bioactive materials (histamine, lectins, endorphins) [12].

Phagocytosis plays an important role in vertebrate and invertebrate systems and Tetrahymena sp. possess features of both single eukaryotic cells and whole organisms [8]. Therefore Slaveykova et al. [13] encourage the use of protists as eukaryotic model organisms more often for investigation of the cellular responses to environmental stress at any level. Touitou et al. [14] used Tetrahymena as a cellular assay to predict drug blood therapeutic levels by measuring morphometric changes based on the similarities between this eukaryotic organism and human cells. They also quantified changes in Tetrahymena thermophila 
cell area as a function of nonsteroidal anti-inflammatory drug (NSAID) concentration by image analysis, and found a correlation with drug effective plasma levels in humans.

The changes in phagocytic activity can be an appropriate fundamental cell based process to investigate physiological effects that often occur at short response times and at low toxicant concentrations $[8,15]$, therefore phagocytic activity of Tetrahymena pyriformis can be an appropriate model system for investigating the potential adverse effect of aquatic micropollutants - including xenoestrogenic compounds - in environmentally relevant concentrations.

Our aim was to find a sensitive ecotoxicity endpoint for the testing of aquatic micropollutants, to detect the adverse effects at environmentally relevant concentrations and with short term response. In order to prove the sensitivity of the phagocytic activity six model compounds were chosen such as atrazine, bisphenol $\mathrm{A}$, dibutyl phthalate, 17 $\beta$-estradiol, 3,4-dichlorophenol and Na-diclofenac.

Amongst the six model substances a pesticide, atrazine and two plasticizers, bisphenol A and dibutyl phthalate were selected based on their endocrine disruptive potential [5, 16-22]. $17 \beta$-estradiol was selected as natural estrogenic compound based on our previous results of $\mathrm{LOEC}=0.1 \mu \mathrm{g} / \mathrm{L}$ according to the Daphnia magna heartbeat rate test [23]. 3,4-dichlorophenol was selected based on its significant toxicity toward Lemna minor $(\mathrm{LOEC}=0.25 \mu \mathrm{g} / \mathrm{L})$ [24]. Na-diclofenac, a nonsteroidal anti-inflammatory drug was also selected based on our previous results of the $D$. magna heartbeat rate test with $\mathrm{LOEC}=0.1 \mu \mathrm{g} / \mathrm{L}$ [24]. Our decision was supported by the Priority List of emerging micropollutants established by Molnár et al. [25]. This list of priority pollutants was prepared taking into consideration the following characteristics: potential risk, hazardous effect, production and use volumes and their occurrence in the river Danube and the treated waste waters in Hungary. The concentration range of these model substances detected in river Danube in the frame of the 'Joint Danube Survey 2 - JDS2' [26] are the following: atrazine: $0.0001-5.6 \mu \mathrm{g} / \mathrm{L}$; bisphenol A: 0.004-0.49 $\mu \mathrm{g} 6 \mathrm{~L}$; dibutyl phthalate: $0.2-7 \mu \mathrm{g} / \mathrm{L} ; 17 \beta$-estradiol: $<0.005 \mu \mathrm{g} / \mathrm{L} ; 3$,4-dichlorophenol: $<0.162 \mu \mathrm{g} / \mathrm{L}$; Na-diclofenac: $0.001-0.13 \mu \mathrm{g} / \mathrm{L}$. According to risk based ranking atrazine, bisphenol A, dibutyl phthalate, 17 $\beta$-estradiol, Na-diclofenac and chloro-phenolic compounds are among the first 30 priority pollutants of this list [25].

Although Na-diclofenac and 3,4-dichlorophenol are present at trace concentrations in the aquatic ecosystem, there has been emerging concern about their biological activities adversely impacting aquatic life and human health $[27,28]$. The primary effects of these contaminants are well known, while their secondary effects on the aquatic ecosystem are largely unknown $[27,28]$. The main sources of the Na-diclofenac and $17 \beta$-estradiol are hospital effluents and communal wastewaters [29]. 3,4-dichlorophenol is generally used as a pesticide or disinfectant, therefore the most typical route to aquatic environments is via agricultural and industrial uses, as well as in case of atrazine [30]. Chlorophenols are widespread in aquatic ecosystems; the toxicity mechanism is uncoupling oxidative phosphorylation for representatives with two or more constituents [31]. Dibutyl phthalate (DBP) is a commonly used plasticizer, the typical route of which to aquatic environments is via industrial uses [29].

\section{Materials and methods}

The ecotoxicity of six organic micropollutants (atrazine, bisphenol A, dibutyl phthalate, 17 $\beta$-estradiol, 3,4-dichlorophenol and Na-diclofenac) was investigated by applying a sublethal physiological ecotoxicity endpoint, the Tetrahymena pyriformis phagocytic activity.

\subsection{Model substances}

Atrazine ( $>97.0 \%, \quad$ CASRN: 1912-24-9) was supplied by KISCHEMICALS Manufacturing and Mercantile LLC. Bisphenol A (239658-50G, $\geq 99 \%$, CASRN: 80-05-7); dibutyl phthalate (CAS RN: 84-74-2, 524980-25ML, 99\%); 17ß-estradiol (CAS RN: 50-28-2, E8875-250MG); 3,4-dichlorophenol (99\%, D70406-5G, CASRN: 95-77-2) and Na-diclofenac (D6899-10G, CASRN: 15307-79-6) were purchased from Sigma Aldrich.

The applied chemical substances were dissolved in distilled water, freshly before testing. The use of solvents was not necessary as all of the substances were water soluble in the tested concentration. In line with the approach of Rivetti et al. [32], to find sensitive response to emerging contaminants at environmentally relevant concentrations applying physiological endpoints, a ten-fold dilution series was applied in a wide concentration range $(0.005-10,000 \mu \mathrm{g} / \mathrm{L})$ (Table 1$)$.

Table 1 Tested concentrations of the model substances

\begin{tabular}{ll}
\hline Model substance & Tested concentration $[\mu \mathrm{g} / \mathrm{L}]$ \\
\hline Atrazine & $0.05 ; 0.5 ; 5 ; 50 ; 500$ \\
Bisphenol A & $0.1 ; 1 ; 10 ; 100 ; 1000$ \\
Dibutyl phthalate & $0.05 ; 0.5 ; 5 ; 50 ; 500$ \\
17ß-estradiol & $0.01 ; 0.1 ; 1 ; 10 ; 100$ \\
3,4-dichlorophenol & $0.005 ; 0.05 ; 0.5 ; 5 ; 50$ \\
Na-diclofenac & $0.01 ; 0.1 ; 1 ; 10 ; 100$ \\
\hline
\end{tabular}

\subsection{Tetrahymena pyriformis cultures}

Tetrahymena cultures (A-759-b) were maintained in the laboratory in PP medium ( $1 \%$ tryptone, $0.1 \%$ yeast extract) with antibiotic mix $(0.2 \%$ penicillin $\mathrm{G}$ sodium, $2 \%$ streptomycin sulphate, $1 \%$ nystatin) under axenic circumstances described by Leitgib et al. [33]. Since in the present work our aim was to screen the toxicity and dose-response of emerging model compounds with this unconventional ecotoxicity endpoint, we did not apply starved cultures. 


\subsection{Test method}

For the assays $24 \mathrm{~h}$ old, exponential growth phase T. pyriformis cultures were prepared by pipetting $5 \mathrm{~mL}$ of the culture into $20 \mathrm{~mL}$ of sterile medium and $600 \mu \mathrm{L}$ of antibiotic mix solution, then Tetrahymena cultures were incubated in a flat bottom flask at $21 \pm 0.5^{\circ} \mathrm{C}$ placed into a shaking incubator at $150 \mathrm{rpm}$ for $24 \mathrm{~h}$. The cultures were checked under microscope for healthy morphology and motility. For the phagocytic activity bioassay, $500 \mu \mathrm{L}$ of $T$. pyriformis cell suspension, $100 \mu \mathrm{L}$ test solution and $400 \mu \mathrm{L}$ Chinese ink solution were pipetted into an Eppendorf micro test tube and incubated for $30 \mathrm{~min}$ at $21 \pm 0.5^{\circ} \mathrm{C}$ under dark circumstances. The Chinese ink solution was prepared with Losina-Losonsky solution [34] and filtered with $0.02 \mu \mathrm{m}$ sterile filter. After $30 \mathrm{~min}$ of contact time the samples were fixed with $20 \mu \mathrm{L} 1.5 \%$ formaldehyde solution. The Chinese ink particle granules formed by phagocytosis (test particles) were counted in 80 cells oculometrically with light microscope (Nikon CH20) under 400x magnification. Each measurement was repeated three times.

\subsection{Statistical analysis}

To determine the effective concentration values (EC) sigmoidal curves were fitted to measurement data.

$\mathrm{EC}_{50}$ values were determined with OriginLab 8.0 software applying Logistic Dose Response Function fitting: $\mathrm{y}=\mathrm{A} 2+(\mathrm{A} 1-\mathrm{A} 2) /\left(1+(\mathrm{x} / \mathrm{x} 0)^{\wedge} \mathrm{p}\right)$.

One-way analysis of variance (ANOVA) was performed by STATISTICA $12^{\circledR}$ software identifying significant effects $(p<0.05)$. Univariate Tests of Significance were performed and the homogeneity of variances was examined. In case of significance, the lowest observed effect concentration (LOEC) value was determined using Dunnett's test $(\alpha=0.05)$. The applied statistical method used in our acute tests was identical to the method used in the case of chronic tests.

\section{Results and discussion}

The modulation of phagocytic activity was investigated as an unconventional physiological measurement endpoint. Fig. 1 represents the average number of test particles (vacuoles) formed by phagocytosis in 240 cells. In addition to Fig. 1, Table 2 and 3 provide data on the inhibition percentage values, LOEC and $\mathrm{EC}_{50}$ values.

Unlike Köhidai et al. [11] we neither applied starved cell cultures, and chemotactic selection, because this simplified methodology has proved to be sensitive to a wide range of micropollutants at environmentally relevant concentrations.

The applied concentration range of the tested model substances was $0.005-1000 \mu \mathrm{g} / \mathrm{L}$ at which levels according to Dunnett's ANOVA significant effect was found in all samples except for the bisphenol A at $100 \mu \mathrm{g} / \mathrm{L}$. Atrazine, dibutyl phthalate, $17 \beta$-estradiol and 3,4-dichlorophenol resulted in concentrationdependent decrease in phagocytic activity (Fig. 1).

The lowest applied atrazine concentration of $0.05 \mu \mathrm{g} / \mathrm{L}$ administered to the cells decreased by $16 \%$ the mean of test particles formed by phagocytosis compared to control, while $0.05 \mu \mathrm{g} / \mathrm{L}$ dibutyl phthalate concentration caused $19 \%$ of inhibition. The lowest effect concentration $(0.01 \mu \mathrm{g} / \mathrm{L})$ in case of $17 \beta$-estradiol resulted in $14 \%$ inhibitory effect.

Table 2 Inhibition percentage values (H\%) of T. pyriformis phagocytic activity test after 30 min of exposure time

\begin{tabular}{|c|c|c|c|c|c|c|c|c|c|c|c|}
\hline \multicolumn{12}{|c|}{ Inhibition (H\%) } \\
\hline $\begin{array}{l}\text { Conc. } \\
{[\mu \mathrm{g} / \mathrm{L}]}\end{array}$ & Atrazine & $\begin{array}{l}\text { Conc } \\
{[\mu \mathrm{g} / \mathrm{L}]}\end{array}$ & $\begin{array}{l}\text { Bisphenol } \\
\text { A }\end{array}$ & $\begin{array}{l}\text { Conc. } \\
{[\mu \mathrm{g} / \mathrm{L}]}\end{array}$ & $\begin{array}{l}\text { Dibutyl } \\
\text { phthalate }\end{array}$ & $\begin{array}{l}\text { Conc. } \\
{[\mu \mathrm{g} / \mathrm{L}]}\end{array}$ & $17 \beta$-estradiol & $\begin{array}{l}\text { Conc. } \\
{[\mu \mathrm{g} / \mathrm{L}]}\end{array}$ & 3,4-dichlorophenol & $\begin{array}{l}\text { Conc. } \\
{[\mu \mathrm{g} / \mathrm{L}]}\end{array}$ & Na-diclofenac \\
\hline 0.05 & 16 & 0.1 & 58 & 0.05 & 19 & 0.01 & 14 & 0.005 & 23 & 0.01 & -36 \\
\hline 0.5 & 35 & 1 & 88 & 0.5 & 22 & 0.1 & 51 & 0.05 & 26 & 0.1 & -42 \\
\hline 5 & 80 & 10 & -67 & 5 & 38 & 1 & 64 & 0.5 & 59 & 1 & -21 \\
\hline 50 & 86 & 100 & -33 & 50 & 48 & 10 & 57 & 5 & 100 & 10 & -29 \\
\hline 500 & 81 & 1000 & 81 & 500 & 74 & 100 & 79 & 50 & 100 & 100 & -30 \\
\hline
\end{tabular}

Table 3 LOEC and $\mathrm{EC}_{50}$ values of the T. pyriformis phagocytic activity test

\begin{tabular}{lllll}
\hline Model substance & LOEC $[\mu \mathrm{g} / \mathrm{L}]$ & $\mathrm{EC}_{50}{ }^{a}[\mu \mathrm{g} / \mathrm{L}]$ & Std. Error & 0.934 \\
\hline 3,4-dichlorophenol & 0.005 & 0.18 & 0.098 & 0.105 \\
17ß-estradiol & 0.01 & 0.07 & - & - \\
Na-diclofenac & 0.01 & - & 0.259 & 0.968 \\
Atrazine & 0.05 & 0.58 & 12.82 & 0.958 \\
Dibutyl phthalate & 0.05 & 29.87 & - & -
\end{tabular}

${ }^{\mathrm{a}} \mathrm{EC}_{50}$ values were derived with OriginLab 8.0 software applying Logistic Function fitting: $\mathrm{y}=\mathrm{A} 2+(\mathrm{A} 1-\mathrm{A} 2) /\left(1+(\mathrm{x} / \mathrm{x} 0)^{\wedge} \mathrm{p}\right)$, where $\mathrm{A} 1$ is the initial value, $\mathrm{A} 2$ is the final value, $\mathrm{x} 0$ is the centre and $\mathrm{p}$ is the power.

-: ambiguous results for $\mathrm{EC}_{50}$ derivation 

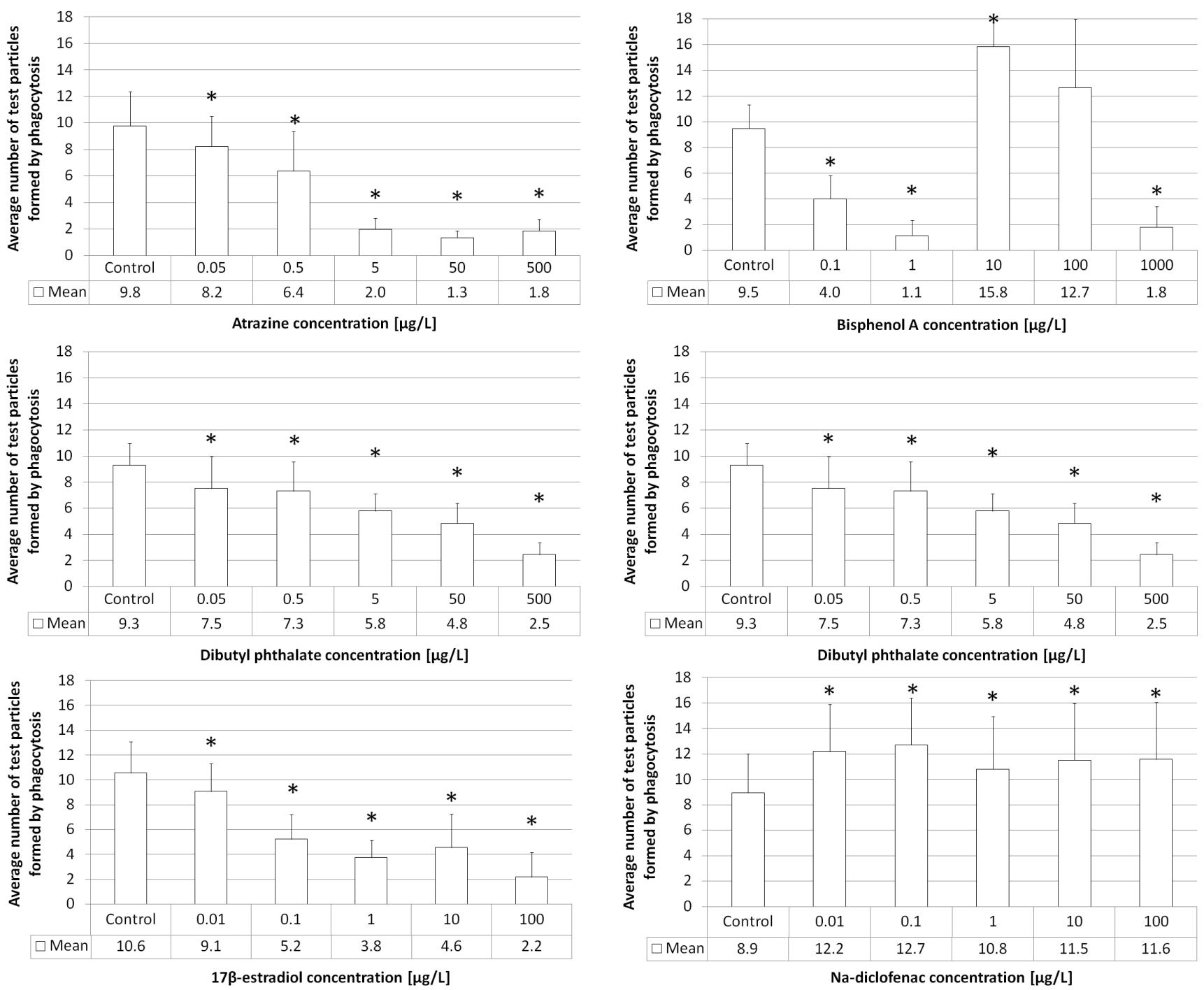

Fig. 1 Average number of test particles formed by phagocytosis. The results are plotted based on the number of observations in 240 cells. Significant effects are marked by asterisk $(*)$, whiskers represent standard deviation (SD).

The phagocytic activity test showed outstanding sensitivity administering 3,4-dichlorophenol at the lowest concentration $(0.005 \mu \mathrm{g} / \mathrm{L})$ with inhibitory effect of $23 \%$. When administering $\mathrm{Na}$-diclofenac at $0.01-100 \mu \mathrm{g} / \mathrm{L}$ concentration range a constant and significant stimulation $(21-42 \%)$ in the phagocytic activity was experienced. In terms of phagocytic activity the most interesting response was experienced in case of the xenoestrogenic compound, bisphenol A: the $0.1-1000 \mu \mathrm{g} / \mathrm{L}$ concentration range did not lead to concentration-dependent response. At the two lowest concentrations $(0.1$ and $1 \mu \mathrm{g} / \mathrm{L})$ and at the highest applied concentration $(1000 \mu \mathrm{g} / \mathrm{L})$, bisphenol A resulted in strong inhibition of the phagocytic activity, while the two intermediate concentrations (10 and $100 \mu \mathrm{g} / \mathrm{L})$ showed opposite effect, significant increase in the number of test particles formed by phagocytosis was experienced.

Comparing the effect values of these model compounds with concentrations determined in surface waters, we can conclude that this method shows high sensitivity even at environmentally realistic concentration.
$17 \beta$-estradiol was detected in surface waters within $0.037 \mathrm{ng} / \mathrm{L}-50 \mathrm{ng} / \mathrm{L}$ concentration range [9, 26, 35], while Tetrahymena pyriformis phagocytic activity assay could indicate the effect of $10 \mathrm{ng} / \mathrm{L} 17 \beta$-estradiol.

Atrazine was detected in the Tejo river basin in $0.24 \mu \mathrm{g} / \mathrm{L}$ concentration [50] and in Lake Vistonis (Greece) in $1.465 \mu \mathrm{g} / \mathrm{L}$ [51]. According to JDS2 [26] atrazine concentrations of $0.0001-5.6 \mu \mathrm{g} / \mathrm{L}$ were detected in river Danube, which are comparable to the detection limit ( $\mathrm{LOEC}=0.05 \mu \mathrm{g} / \mathrm{L}$ ) of Tetrahymena pyriformis phagocytic activity assay.

In natural waters, BPA is usually present at low concentrations $(<0.01-1.9 \mu \mathrm{g} / \mathrm{L})$ [52]. According to JDS2 [26] BPA concentrations of $0.004-0.49 \mu \mathrm{g} / \mathrm{L}$ were detected in river Danube. BPA was detected in Lake Donghu (China) between 0.02 and $0.534 \mu \mathrm{g} / \mathrm{L}[53]$, in Elbe river $(0.009-0.776 \mu \mathrm{g} / \mathrm{L})$ and in the North Sea about 1 order of magnitude lower [54]. Taking into consideration these surface water concentrations of BPA, Tetrahymena pyriformis phagocytic activity assay is a feasible bioassay for the detection of the effect of this 
industrial additive with its outstanding sensitivity to BPA ( $\mathrm{LOEC}=0.1 \mu \mathrm{g} / \mathrm{L})$.

Dibutyl phthalate was detected in some drinking water supplies at levels ranging from 0.1 to $5 \mu \mathrm{g} / \mathrm{L}$ [55], while based on the JDS2 [26] results, dibutyl phthalate concentrations of $0.2-7 \mu \mathrm{g} / \mathrm{L}$ were detected in river Danube. Tetrahymena pyriformis phagocytic activity assay was sensitive to $0.05 \mu \mathrm{g} / \mathrm{L}$ dibutyl phthalate, therefore it is a sensitive bioassay for the detection of dibutyl phthalate in environmentally realistic concentrations.

The maximum diclofenac concentration of $0.103 \mu \mathrm{g} / \mathrm{L}$ detected in Berlin and $0.13 \mu \mathrm{g} / \mathrm{L}$ detected in river Danube were reported by Heberer et al. [56] and by the JDS2 [26]. The Tetrahymena pyriformis phagocytic activity assay gave a sensitive response to Na-diclofenac at $0.01 \mu \mathrm{g} / \mathrm{L}$ concentration. The constant and significant stimulating effect within the tested concentration range $(0.01-100 \mu \mathrm{g} / \mathrm{L})$ may be an important response as well, in accordance with Kermiche et al. [57]. Their results show that Paramecium sp. cells exposure to low concentrations of ibuprofen $(1$ and $10 \mu \mathrm{g} / \mathrm{L})$ induces insignificant stimulation of cell growth and respiratory metabolism.

Chlorophenolic compounds can be found in aquatic environments at up to $\mu \mathrm{g} / \mathrm{L}$ concentration level.

According to JDS2 [26] a maximum 3,4-dichlorophenol concentration of $0.162 \mu \mathrm{g} / \mathrm{L}$ was detected in river Danube, while the Tetrahymena pyriformis phagocytic activity assay proved to be sensitive to 3,4-dichlorophenol at $0.005 \mu \mathrm{g} / \mathrm{L}$, which can be the result of multiple mechanisms of action. Schüürmann et al. [58] investigated the toxic mechanism associated to phenolic compounds toward Tetrahymena pyriformis. Several potential mode of action was reported, such as the scavenging and generating reactive oxygen species or the ability to act as oxidative uncouplers through a distinct shuttle mechanism across the inner membrane of mitochondria.

Phenolic compounds may increase electrophilicity leading to an impairment of proteins (receptors, enzymes) and nucleic acids (DNA, RNA). An important mode of their toxic action toward aquatic organisms is polar narcosis [59]. Schultz et al. [60] also highlighted endocrine disruption (estrogenicity in particular) as potential mode of action of phenolic compounds.

In our experiments beside a natural estrogenic compound, $17 \beta$-estradiol, atrazine, bisphenol A, dibutyl phthalate and 3,4-dichlorophenol were investigated as proved or suspected xenoestrogenic compounds. Tetrahymena spp. possess endogenous steroids [61] like cell-lines from mammals but the equivalents to mammalian steroid receptors cells have not been found yet [8], though Tetrahymena can be influenced by these environmental estrogens by steroid-like receptor structures induced by administering exogenous steroid hormones [11]. A sensitive concentration-dependent response was found in case of atrazine, 17 $\beta$-estradiol, dibutyl phthalate and 3,4-dichlorophenol which alteration in the phagocytic activity may be due to "hormonal" disturbance of homeostasis.
In case of bisphenol A, non-monotonic dose-response was confirmed by a large set of independently performed experiments. Extensive data can be found in current literature regarding non-monotonic, unusual dose response curves - including U-shaped and inverted U-shaped curves - demonstrated for natural hormones and endocrine disrupting chemicals [62-64].

U-shaped dose-response curves occur when the maximal response is produced at very low and very high concentrations, but not at intermediate ones; inverted U-shaped curves are the inverse. U-shaped and inverted U-shaped curves are extremely controversial in ecotoxicology, because they contradict the long-held belief that dose-response relationships are linear [62]. This non-monotonic dose-response is very common (occurring in greater than $20 \%$ of all experiments) in case of BPA in a variety of biological systems including cultured cells and laboratory animals. This non-conventional dose-response is explained by the overlapping monotonic curves of individual mode of actions resulting non-monotonic dose response as the resultant of these overlapping, complex physiological processes. The well-studied potential mechanisms underlying the phenomenon of non-monotonicity may be the effect of hormone concentration on the number of receptors, namely when the number of the produced receptors differs from the number of degraded receptors, this way attenuating the response while the hormone concentration increases. Desensitization can also affect the response of some receptors at higher doses, when receptors are biochemically inactivated upon increasing hormone concentrations. Receptor selectivity, receptor competition and endocrine negative feedback loops can also cause non-monotonicity [63]. The growing recognition of the nonlinear dose-response relationships problems calls for more studies. So far the non-monotonic dose-response phenomenon has been confirmed in case of other emerging micropollutants in some studies $[62,64]$.

BPA can act through multiple mechanisms such as electron transfer, generation of reactive oxygen species (ROS) and oxidative stress (OS) in addition to endocrine disrupting effect [65].

Correspondingly, to many NSAIDs, diclofenac exerts its effect through inhibiting the prostaglandin synthesis via inhibiting cyclooxygenase- 1 and cyclooxygenase-2. Current research shows that pharmacologic activity of diclofenac goes beyond cyclooxygenase inhibition, and may include novel mode of actions [66]. Based on our results the T. pyriformis phagocytic activity test can be a sensitive tool for the detection of Na-diclofenac present in environmental samples.

Table 4 shows data on current literature concerning the sensitivity of conventionally applied ecotoxicological test methods, such as the Microtox test with Aliivibrio fischeri, the Daphnia magna immobilization test and the $T$. pyriformis proliferation inhibition test. The T. pyriformis phagocytic activity test besides being very simple, rapid and easy to perform, it has outstanding sensitivity compared to the conventionally applied test methods. 
Table 4 Literature data on the sensitivity of conventionally applied ecotoxicological test methods

\begin{tabular}{llll}
\hline Model substance & $\begin{array}{l}\text { Aliivibrio fischeri bioluminescence } \\
\text { (Microtox) }\end{array}$ & $\begin{array}{l}\text { Daphnia magna } \\
\text { immobilization }\end{array}$ & $\begin{array}{l}\text { Tetrahymena pyriformis } \\
\text { proliferation }\end{array}$ \\
\hline 17ß-estradiol & $\mathrm{EC}_{40,30 \mathrm{~min}}: 0.01 \mathrm{mg} / \mathrm{L}[36]$ & $\mathrm{EC}_{50,24 \mathrm{~h}}: 3.67 \mathrm{mg} / \mathrm{L}[19]$ & - \\
\hline Diclofenac & $\mathrm{EC}_{50,30 \mathrm{~min}}: 13.5 \mathrm{mg} / \mathrm{L}[37]$ & $\mathrm{EC}_{50,24 \mathrm{~h}}: 48.5 \mathrm{mg} / \mathrm{L}[38]$ & $\mathrm{EC}_{30,30 \mathrm{~min}}: 0.0296 \mathrm{mg} / \mathrm{L}[39]$ \\
\hline Bisphenol A & $\mathrm{EC}_{50,30 \mathrm{~min}}: 4-103 \mathrm{mg} / \mathrm{L}[40]$ & $\mathrm{EC}_{50,48 \mathrm{~h}}: 8.91 \mathrm{mg} / \mathrm{L}[41]$ & - \\
\hline 3,4-dichlorophenol & $\mathrm{EC}_{50,30 \mathrm{~min}}: 4.38 \mathrm{mg} / \mathrm{L}[42]$ & $\mathrm{EC}_{50,24 \mathrm{~h}}: 2.5 \mathrm{mg} / \mathrm{L}[43]$ & $* * \mathrm{EC}_{50,24 \mathrm{~h}}: 3.69 \mathrm{mg} / \mathrm{L}[44]$ \\
\hline Dibutyl phthalate & $\mathrm{EC}_{50,30 \mathrm{~min}}: 10.9 \mathrm{mg} / \mathrm{L}[45]$ & $\mathrm{EC}_{50,24 \mathrm{~h}}: 10.35 \mathrm{mg} / \mathrm{L}[45]$ & $\mathrm{EC}_{50,24 \mathrm{~h}}: 2.2 \mathrm{mg} / \mathrm{L}[46]$ \\
\hline Atrazine & $\mathrm{EC}_{50,30 \mathrm{~min}}: 3.8 \mathrm{mg} / \mathrm{L}[47]$ & LC $_{50,48 \mathrm{~h}}: 60.6 \mathrm{mg} / \mathrm{L}[48]$ & $\mathrm{EC}_{50,9 \mathrm{~h}}: 66.5 \mathrm{mg} / \mathrm{L}[49]$ \\
\hline
\end{tabular}

*Carried out with Daphnia carinata.

**Carried out with Tetrahymena termophyla; 2,4-dichlorophenol

The Microtox test was the most sensitive to $17 \beta$-estradiol $\left(\mathrm{EC}_{46,30 \mathrm{~min}}=10 \mu \mathrm{g} / \mathrm{L}\right.$ concentration) [36], but in case of the other tested model substances (atrazine, bisphenol A, dibutyl phthalate, 3,4-dichlorophenol and Na-diclofenac) it was sensitive only at $\mathrm{mg} / \mathrm{L}$ concentration levels [37, 40, 45, 47]. The T. pyriformis phagocytic activity test proved to be sensitive to the tested model substances in the $0.005-0.1 \mu \mathrm{g} / \mathrm{L}$ concentration range. The $\mathrm{EC}_{50}$ values of the D. magna immobilization test were found at $\mathrm{mg} / \mathrm{L}$ concentration level $[19,38,41,43,45,48]$ compared to the $\mathrm{EC}_{50}$ values $(0.07-$ $29.87 \mu \mathrm{g} / \mathrm{L}$ ) of the T. pyriformis phagocytic activity test. We found literature data on T. pyriformis proliferation inhibition test only for atrazine, dibutyl phthalate, 3,4-dichlorophenol and Na-diclofenac. Based on their $\mathrm{EC}_{50}$ values $(0.0296-66.5 \mathrm{mg} / \mathrm{L})$ $[39,44,46,49]$, it can be concluded, that the phagocytic activity test exhibited higher sensitivity (at lower concentration levels) to the tested substances compared to the other above mentioned well established acute ecotoxicity tests. (Table 4). In summary we can state that $T$. pyriformis phagocytic activity test has the highest sensitivity to the tested chemicals.

The outcomes of our study suggest, similarly to the chemotaxis assay applied by Láng and Köhidai [39], that alterations in the phagocytic activity may be used as a qualitative response that nevertheless can indicate sublethal effect at environmental concentrations.

\section{Conclusion}

Phagocytosis as one of the most basic cell physiological activities plays a crucial role in nutrition, immunological responses and chemotaxis. Our screening study confirms the benefit of this cost-effective physiological endpoint in assessing the impact of micropollutants, with a highly sensitive sublethal reaction that was elicited by a variety of biologically active compounds at low concentrations. These results emphasize the importance of sublethal physiological ecotoxicological endpoints to assess and characterize the effects of micropollutants. Our results furnishing rapid and sensitive response demonstrate the potential of this test to be applied as an early warning assay.

\section{Acknowledgement}

The financial supports of the National Innovation Office (TECH_08-A4/2-2008-0161, CDFILTER project and TECH_09-A4-2009-0129, SOILUTIL project) and the New Hungary Development Plan (TÁMOP-4.2.1/B-09/1/KMR-20100002 ) are greatly acknowledged. We are grateful to Emese Vaszita for her contribution to language editing of the manuscript.

\section{SUPPORTED THROUGH THE NEW NATIONAL EXCELLENCE PROGRAM OF THE MINISTRY OF HUMAN CAPACITIES.}

\section{References}

[1] Hewitt, L. M., Parrott, J. L., McMaster, M. E. "A decade of research on the environmental impacts of pulp and paper mill effluents in Canada: Sources and characteristics of bioactive substances." Journal of Toxicology and Environmental Health, Part B. 9(4), pp. 341-356. 2006. https://doi.org/10.1080/15287390500195976

[2] Wartman, C. A., Hogan, N. S., Hewitt, L. M., McMaster, M. E., Landman, M. J., Taylor, S., Kovacs, T. G., van den Heuvel, M. R. "Androgenic effects of a Canadian bleached kraft pulp and paper effluent as assessed using threespine stickleback (Gasterosteus aculeatus)." Aquatic Toxicology. 92(3), pp. 131-139. 2009.

https://doi.org/10.1016/j.aquatox.2009.02.003

[3] Frye, C. A., Bo, E., Calamandreis, G., Calzà, L., Dessì-Fulgheri, F., Fernández, M., Fusani, L., Kah, O., Kajta, M., Page, Y. L., Patisaul, H. B., Venerosi, A., Wojtowicz, A.K., Panzica, G.C. "Endocrine disrupters: a review of some sources, effects, and mechanisms of actions on behaviour and neuroendocrine systems." Journal of Neuroendocrinology. 24, pp. 144-159. 2011. https://doi.org/10.1111/j.1365-2826.2011.02229.x

[4] Jin, S., Yang, F., Xu, Y., Dai, H., Liu, W. "Risk assessment of xenoestrogens in a typical domestic sewage-holding lake in China." Chemosphere. 93(6), pp. 892-898. 2013.

https://doi.org/10.1016/j.chemosphere.2013.05.037

[5] Zhao, J. L., Chen, X. W., Yan, B., Wei, C., Jiang, Y. X., Ying, G. G. "Estrogenic activity and identification of potential xenoestrogens in a coking wastewater treatment plant." Ecotoxicology and Environmental Safety. 112, pp. 238-246. 2015.

https://doi.org/10.1016/j.ecoenv.2014.11.012

[6] Sultan, C., Balaguer, P., Terouanne, B., Georget, V., Paris, F., Jeandel, C., Lumbroso, S., Nicolas, J. "Environmental xenoestrogens, antiandrogens and disorders of male sexual differentiation." Molecular and Cellular Endocrinology. 178(1-2), pp. 99-105. 2001. https://doi.org/10.1016/S0303-7207(01)00430-0 
[7] Kase, R., Kunz, P., Gerhardt, A. "Identifikation geeigneter Nachweismöglichkeiten von hormonaktiven und reproduktionstoxischen Wirkungen in aquatischen Ökosystemen." Umweltwissenschaften und Schadstoff-Forschung. 21(4), pp. 339-378. 2009. (in German) https://doi.org/10.1007/s12302-009-0072-2

[8] Gerhardt, A., Ud-Daula, A., Schramm, K. "Tetrahymena spp. (protista, ciliophora) as test species in rapid multi-level ecotoxicity tests." Acta Protozool. 49(4), pp. 271-280. 2010.

[9] Esteban, S., Gorga, M., Petrovic, M., González-Alonso, S., Barceló, D., Valcárcel, Y. "Analysis and occurrence of endocrine-disrupting compounds and estrogenic activity in the surface waters of Central Spain." Science of the Total Environment. 466-467, pp. 939-951. 2014. https://doi.org/10.1016/j.scitotenv.2013.07.101

[10] Gerhardt, A. "Behavioural ecotoxicology - prospects and limitations." Human and Ecological Risk Assessment: An International Journal. 13, pp. 481-491. 2007. https://doi.org/10.1080/10807030701340839

[11] Köhidai, L., Lovas, B., Csaba, Gy. "Effect of adrenocorticotropic hormone (ACTH) and insulin on the phagocytic capacity of Tetrahymena." Zoological Society of Japan. 12(3), pp. 277-281. 1995. https://doi.org/10.2108/zsj.12.277

[12] Kovacs, P., Sundermann, C. A., Csaba, G. "Investigations of receptormediated phagocytosis by hormone-induced (imprinted) Tetrahymena pyriformis." Experientia. 52(8), pp. 769-773. 1996.

[13] Slaveykova, V., Sonntag, B., Gutiérrez, J. C. "Stress and Protists: No life without stress." European Journal of Protistology. 55, pp. 39-49. 2016. https://doi.org/10.1016/j.ejop.2016.06.001

[14] Touitou, E., Godin, B., Klein, H., Ron, A. "In vitro estimation of effective NSAIDs plasma concentrations in humans by measuring morphometric changes in Tetrahymena." Journal of Drug Delivery Science and Technology. 17(3), pp. 163-167. 2007. https://doi.org/10.1016/S1773-2247(07)50030-4

[15] Doi, M., Kawaguchi, I., Tanaka, N., Fuma, S., Ishii, N., Miyamoto, K., Takeda, H., Kawabata, Z. "Model ecosystem approach to estimate community level effects of radiation." Radiprotection. 40(Suppl. 1), pp. 913-919. 2005. https://doi.org/10.1051/radiopro:2005s1-134

[16] Gascón, J., Oubiña, A., Barceló, D. "Detection of endocrine-disrupting pesticides by enzyme-linked immunosorbent assay (ELISA): application to atrazine." TrAC Trends in Analytical Chemistry. 16(10) pp. 554-562. 1997. https://doi.org/10.1016/S0165-9936(97)00051-4

[17] El-Mubarak, A., Huisingh, D. "Environmental xenoestrogens: shortterm exposure of low doses of lindane, dieldrin, dibutyl phthalate, and diethylhexyl phthalate increases uterine weight in young female mice." Analytical Sciences. 17, pp. 261-264. 2001. https://doi.org/10.14891/analscisp.17icas.0.i261.0

[18] Crain A., Guillette Jr. L. J. "Environmental Endocrine Disruptors: An Evolutionary Perspective." Taylor \& Francis. New York. 2005.

[19] Brennan, S. J., Brougham, C. A., Roche, J. J., Fogarty, A. M. "Multigenerational effects of four selected environmental oestrogens on Daphnia magna." Chemosphere. 64(1), pp. 49-55. 2006. https://doi.org/10.1016/j.chemosphere.2005.11.046

[20] Ortiz-Zarragoitia, M., Trant, J. M., Cajaravillet, M. P. "Effects of dibutylphthalate and ethynylestradiol on liver peroxisomes, reproduction, and development of zebrafish (Danio rerio)." Environmental Toxicology Chemistry. 25(9), pp. 2394-2404. 2006. https://doi.org/10.1897/05-456R.1

[21] Rider, C. V., Hartig, P. C., Cardon, M. C., Lambright, C. R., Bobseine, K. L., Guillette, L. J., Gray, L. E., Wilson, V. S. "Differences in sensitivity but not selectivity of xenoestrogen binding to alligator versus human estrogen receptor alpha." Environmental Toxicology Chemistry. 29(9), pp. 2064-2071. 2010. https://doi.org/10.1002/etc.233
[22] Casa-Resino, I., Valdehita, A., Soler, F., Navas, J. M., Pérez-López, M. "Endocrine disruption caused by oral administration of atrazine in European quail (Coturnix coturnix coturnix)." Comparative Biochemistry and Physiology Part C: Toxicology \& Pharmacology. 156(3-4), pp 159-165. 2012. https://doi.org/10.1016/j.cbpc.2012.07.006

[23] Fekete-Kertész, I., Kunglné-Nagy, Zs., Molnár, M. "Ecological impact of micropollutants on aquatic life determined by an innovative sublethal endpoint Daphnia magna heartbeat rate." Carpathian Journal of Earth and Environmental Sciences. 11(2), pp. 345-354. 2016.

[24] Fekete-Kertész, I., Kunglné-Nagy, Zs., Gruiz, K., Magyar, Á., Farkas, É., Molnár, M. "Assessing toxicity of organic aquatic micropollutants based on the total chlorophyll content of Lemna minor as a sensitive endpoint." Periodica Polytechnica Chemical Engineering. 59(4), pp. 262-271. 2015. https://doi.org/10.3311/PPch.8077

[25] Molnár, M., Gruiz, K., Hajdu, Cs., Nagy, Zs., Fenyvesi, É. "Tiered approach for environmental risk assessment of emerging pollutants in aquatic systems. In: Proceedings of AQUACONSOIL 2013: 12th International UFZ-Deltares Conference on Groundwater-Soil-Systems and Water Resources Management." Barcelona, Spain, 2013.04.162013.04.19. PAPER 2381.

[26] JDS-2. Joint Danube Survey 2 - Final Scientific Report. [Internet]. Available from: http://www.icpdr.org/jds/ [Accessed: 14th January 2017].

[27] Fent, K., Weston, A. A., Caminada, D. "Ecotoxicology of human pharmaceuticals." Aquatic Toxicology. 76, pp. 122-159. 2006. https://doi.org/10.1016/j.aquatox.2005.09.009

[28] Ferrari, B., Paxeus, N., Giudice, R. L., Pollio, A., Garric, J. "Ecotoxicological impact of pharmaceuticals found in treated wastewaters: study of carbamazepine, clofibric acid, and diclofenac." Ecotoxicology and Environmental Safety. 55, pp. 359-370. 2003. https://doi.org/10.1016/S0147-6513(02)00082-9

[29] Deblonde, T., Cossu-Leguille, C., Hartemann, P. "Emerging pollutants in wastewater: A review of the literature." International Journal of Hygiene and Environmental Health. 214, 442-448. 2012.

https://doi.org/10.1016/j.ijheh.2011.08.002

[30] Jensen, J. "Chlorophenols in the Terrestrial Environment." Reviews of Environmental Contamination and Toxicology. 146, pp. 25-51. 1996.

[31] Penttinen, O. P. "Chlorophenols in aquatic environments: Structure activity correlations." Annales Zoologici Fennici. 32, pp. 287-294. 1995.

[32] Rivetti, C., Campos, B., Barata, C. "Low environmental levels of neuro-active pharmaceuticals alter phototactic behaviour and reproduction in Daphnia magna." Aquatic Toxicology. 170, pp. 289-296. 2016. https://doi.org/10.1016/j.aquatox.2015.07.019

[33] Leitgib, L., Kálmán, J., Gruiz, K. "Comparison of bioassays by testing whole soil and their water extract from contaminated sites." Chemosphere. 66, pp. 428-434. 2007. https://doi.org/10.1016/j.chemosphere.2006.06.024

[34] Schiess, N., Csaba, G., Kőhidai, L. "Chemotactic selection with insulin, di-iodotyrosine and histamine alters the phagocytotic responsiveness of Tetrahymena." Comparative Biochemistry and Physiology Part C: Toxicology \& Pharmacology. 128(4), pp. 521-530. 2001. https://doi.org/10.1016/S1532-0456(01)00169-7

[35] Meffe, R., de Bustamante, I. "Emerging organic contaminants in surface water and groundwater: A first overview of the situation in Italy." Science of The Total Environment. 481, pp. 280-295. 2014. https://doi.org/10.1016/j.scitotenv.2014.02.053

[36] Surujlal-Naicker, S., Gupta, S. K., Bux, B. "Evaluating the Acute Toxicity of Estrogen Hormones and Wastewater Effluents Using Vibrio fischeri" Human and Ecological Risk Assessment: An International Journal. 21(4), pp. 1094-1108. 2014. https://doi.org/10.1080/10807039.2014.955767 
[37] Mehinto, A.C. "Impacts of the human pharmaceutical diclofenac in the aquatic environment." Thesis for the degree of Doctor of Philosophy, University of Exeter, 2009. http://hdl.handle.net/10036/94969

[38] Haap, T., Triebskorn, R., Köhler, H. R. "Acute effects of diclofenac and DMSO to Daphnia magna: Immobilisation and hsp70-induction." Chemosphere. 73, pp. 353-359. 2008. https://doi.org/10.1016/j.chemosphere.2008.05.062

[39] Láng, J., Köhidai, L. "Effects of the aquatic contaminant human pharmaceuticals and their mixtures on the proliferation and migratory responses of the bioindicator freshwater ciliate Tetrahymena." Chemosphere. 89, pp. 592-601. 2012.

https://doi.org/10.1016/j.chemosphere.2012.05.058

[40] Liu, H. L., Liu, X.H., Wang, X.Y., Wang, X.R., Yu, H.X. "Toxicity of BPA and TBBPA to Daphnia magna and zebrafish Brachydanio rerio." Huan Jing Ke Xue. 28(8), pp. 1784-1787. 2007.

[41] Huang, G. L., Sun, H. W., Song, Z. H. "Interactions Between Dibutyl Phthalate and Aquatic Organisms." Bulletin of Environmental Contamination and Toxicology. 63, pp. 759-765. 1999. https://doi.org/10.1007\%2Fs001289901044?LI=true

[42] Kurvet, I., Ivask, A., Bondarenko, O., Sihtmäe, M., Kahru, A. "LuxC$D A B E$ - Transformed Constitutively Bioluminescent Escherichia coli for Toxicity Screening: Comparison with Naturally Luminous Vibrio fischer." Sensors. 11, pp. 7865-7878. 2011. https://doi.org/10.3390/s110807865

[43] Kühn, R., Pattard, M., Pernak, K. D., Winter, A. "Results of the harmful effects of selected water pollutants (anilines, phenols, aliphatic compounds) to Daphnia magna." Water Research. 23(4), pp. 495-499. 1989. https://doi.org/10.1016/0043-1354(89)90141-3

[44] Li, Y. J., Cui, Y. B., Jiang, L. J., Dou, J., Li, M. "Toxicity of three chlorophenols to protozoa Tetrahymena thermophila." Huan Jing Ke Xue. 35(7), pp. 2755-61. 2014. (in Chinese)

[45] DBP MSDS. Dibutyl-phthalate MSDS. [Online]. Available from: http:// www.acros.com/portal/alias__Rainbow/lang_en/tabID_41/DesktopDefault.aspx. [Accessed: 1st June 2017].

[46] WHO. "Environmental Health Criteria 189: Di-n-butyl phthalate." [Online]. Available from: http://www.inchem.org/pages/ehc.html. [Accessed 1st March 2017].

[47] Blaise, C., Férard, J. F. (Eds.) "Small-scale Freshwater Toxicity Investigations: Volume 1 - Toxicity Test Methods." Springer Netherlands. 2005.

[48] He, H., Yu, J., Chen, G., Li, W., He, J., Li, H. "Acute toxicity of butachlor and atrazine to freshwater green alga Scenedesmus obliquus and cladoceran Daphnia carinata." Ecotoxicology and Environmental Safety. 80, pp. 91-96. 2012.

https://doi.org/10.1016/j.ecoenv.2012.02.009

[49] Bonnet, J. L., Bonnemoy, F., Dusser, M., Bohatier, J. "Toxicity Assessment of the Herbicides Sulcotrione and Mesotrione Toward Two Reference Environmental Microorganisms: Tetrahymena pyriformis and Vibrio fischeri." Archives of Environmental Contamination and Toxicology. 55, pp. 576-583. 2008. https://doi.org/10.1007/s00244-008-9145-2

[50] Silva, E., Daam, M. A., Cerejeira, M. J. "Aquatic risk assessment of priority and other river basin specific pesticides in surface waters of Mediterranean river basins." Chemosphere. 135, pp. 394-402. 2015. https://doi.org/10.1016/j.chemosphere.2015.05.013

[51] Papadakis, E. N., Vryzas, Z., Kotopoulou, A., Kintzikoglou, K., Makris, K. C., Mourkidou, P. E. "A pesticide monitoring survey in rivers and lakes of northern Greece and its human and ecotoxicological risk assessment." Ecotoxicology and Environmental Safety. 116, pp. 1-9. 2015. https://doi.org/10.1016/j.ecoenv.2015.02.033
[52] Olmez-Hanci, T., Dursun, D., Aydin, E., Arslan-Alaton, I., Girit, B., Mita, L., Diano, N., Mita, G., Guida, D. M. " $\mathrm{S}_{2} \mathrm{O}_{82}-/ \mathrm{UV}-\mathrm{C}$ and $\mathrm{H}_{2} \mathrm{O}_{2} /$ UV-C treatment of Bisphenol A: Assessment of toxicity, estrogenic activity, degradation products and results in real water." Chemosphere. 119, pp. 115-123. 2015. https://doi.org/10.1016/j.chemosphere.2014.06.020

[53] Jin, X., Gao, J., Zha, J., Xu, Y., Wang, Z., Giesy, J. P., Richardson K. L. "A tiered ecological risk assessment of three chlorophenols in Chinese surface waters." Environmental Science and Pollution Research. 19(5), pp. 1544-1554. 2012. https://doi.org/10.1007/s11356-011-0660-8

[54] Heemken, O. P., Reincke, H., Stachel, B., Theobald, N. "The occurrence of xenoestrogens in the Elbe river and the North Sea." Chemosphere. 45(3), pp. 245-259. 2001. https://doi.org/10.1016/S0045-6535(00)00570-1

[55] ATDSR - Agency for Toxic Substances and Disease Registry (ATSDR). Toxicological Profile for Di-n-Butyl Phthalate. Public Health Service, U.S. Department of Health and Human Services. 1990.

[56] Heberer, T. "Occurrence, fate, and removal of pharmaceutical residues in the aquatic environment: a review of recent research data." Toxicolgy Letters. 131, pp. 5-17. 2002. https://doi.org/10.1016/S0378-4274(02)00041-3

[57] Kermiche, F., Berrebah, H., Djebar, M. R. "Toxicological effects of drugs (Diclofenac, Ibuprofen, mixture) and Hormesis on a non-target organism: Paramecium sp." Journal of Entomology and Zoology Studies. 4(5), pp. 187-191. 2016.

[58] Schüürmann, G., Aptula, A. O., Kühne, R., Ebert, R. U. "Stepwise discrimination between four modes of toxic action of phenols in the Tetrahymena pyriformis assay." Chemical Research in Toxicology. 16(8), pp. 974-987. 2003. https://doi.org/10.1021/tx0340504

[59] Schultz, T. W., Sinks, G. D., Cronin, M. T. D. "Identification of mechanisms of toxic action of phenols to Tetrahymena pyriformis from molecular descriptors." In: Chen, F., Schüürmann, G. (Eds.), Quantitative Structure-Activity and Relationships in Environmental Sciences-VII. SETAC Press, Pensacola, FL, USA, pp. 329-342. 1997.

[60] Schultz, T. W., Sinks, G. D., Cronin, M. T. D. "Effect of substituent size and dimensionality on potency of phenolic xenoestrogens evaluated with a recombinant yeast assay." Environmental Toxicology Chemistry. 19(11), pp. 2637-2642. 2000. https://doi.org/10.1002/etc.5620191104

[61] Csaba, G., Inczefi-Gonda, Á., Fehér, T. "Induction of steroid binding sites (receptors) and presence of steroid hormones in the unicellular Tetrahymena pyriformis." Comparative Biochemistry and Physiology Part A: Physiology. 82(3), pp. 567-570. 1985. https://doi.org/10.1016/0300-9629(85)90434-7

[62] Clotfelter, E. D., Bell, A. M., Levering, K. R. "The role of animal behaviour in the study of endocrine-disrupting chemicals." Animal Behaviour. 68(4), pp. 665-676. 2004. https://doi.org/10.1016/j.anbehav.2004.05.004

[63] Vandenberg, L. N. "Non-Monotonic Dose Responses in Studies of Endocrine Disrupting Chemicals: Bisphenol A as a Case Study." Dose Response. 12(2), pp. 259-276. 2014.

https://doi.org/10.2203/dose-response.13-020.Vandenberg

[64] Lagarde, F., Beausoleil, C., Belcher, S. M., Belzunces, L. P., Emond, C., Guerbet, M., Rousselle C. "Non-monotonic dose-response relationships and endocrine disruptors: a qualitative method of assessment." Environmental Health. 14, 13. 2015. https://doi.org/10.1186/1476-069X-14-13

[65] Kovacic, P. "How safe is bisphenol A? Fundamentals of toxicity: Metabolism, electron transfer and oxidative stress." Medical Hypotheses. 75(1), pp. 1-4. 2010. https://doi.org/10.1016/j.mehy.2010.03.002

[66] Gan, T. J. "Diclofenac: an update on its mechanism of action and safety profile." Current Medical Research and Opinion. 26(7), pp. 1715-1731. 2010. https://doi.org/10.1185/03007995.2010.486301 